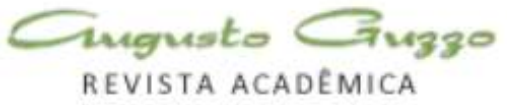

\title{
Neuroplasticity: Changing Minds And Changing Brains
}

\author{
James Bylund, Psy.D., ABSNP.
}

\begin{abstract}
Dr. James Bylund é doutor em Psicologia educacional pela Alliant International University, em San Diego, na Califórnia. Mestre em Educação e Especialista em Psicologia Educacional pela San Diego State University, na Califórnia, EUA. É Especialista em neuropsicológica educacional e Credenciado a atuar como Psicólogo Educacional em todo território dos Estados Unidos. Trabalhou como psicólogo nas escolas públicas de San Diego e como coordenador de programas especiais na região de Contra Costa, na Califórnia, EUA. Atualmente, é diretor de serviços de apoio ao estudante nas escolas públicas de Byron, na Califórnia, atende em seu consultório particular e leciona cursos de avaliação neuropsicológica na Alliant International University.
\end{abstract}

\begin{abstract}
As a school psychologist I have found that many of the students, parents, and educators that I work, with believe that intelligence is a "fixed" trait. Despite popular belief, however, as we learn more about the structure and function of the brain it is increasingly clear that the brain changes as we learn from, and adapt to, environmental demands. These changes in the structure and function of the brain in turn produce changes in behavior, and I use behavior to refer to any observable action including the demonstration of cognitive and academic skills. In the following article I discuss the topic of neuroplasticity citing the work. Mark. Rosenwieg and Michael Merzenich, two of the foremost researchers on the topic. Further, I discuss some implications of neuroplasticity on the practice of school psychology.
\end{abstract}

Key words: Psychologist, environmental, skills, cognitive. Work. 
Consistent with the data presented by

\section{Introduction}

\section{Principles Of Neuroplasticity}

Neuroplasticity is a term used to describe the brains ability to change in response to one's experiences, and over the past 40 years Mark Rosenzweig and his colleagues at UC Berkeley have demonstrated that both the brain and behavior of laboratory rats changes as a result of different environmental demands (Rosenzweig, 2003). Rosenzweig (2003) has found that laboratory rats exposed to greater social interaction and stimulating environments develop larger neurons, a greater number of dendrites, and increased branching of dendrites. Not only do changes occur in the brains of these rats, but their problem solving skills improve as well, as demonstrated by their performances on spatial mazes. While a great deal of research has been done with laboratory rats, similar results have been demonstrated in all species for which research has been conducted including birds, cats, monkeys, and humans (Rosenzweig, 2003). While Rosenzweig (2003) has cautioned against the overgeneralization of such findings, he concludes that "the variety of findings on plasticity are encouraging for education and for the recovery of function" (p. 536).
Rosenzweig (2003), Buonomano and Merzenich (1998) write that the brain is not a fixed entity but rather a dynamic structure that is continuously altered by one's behavioral experiences. In reviewing decades of research on neuroplasticity, Buonomano and Merzenich (1998) speculate that plasticity at the level of the synapse underlies the plasticity of larger cortical maps. One of the mechanisms involved in synaptic plasticity is the process of Long-Term Potentiation (LTP) in which "simultaneous pre-and post synaptic activity results in the strengthening of the synaptic connection" ( $p$. 154). In other words, the more frequently the connection between two neurons is activated the stronger and more efficient that connection becomes. This rule is at the heart of Hebbian plasticity (Donald Hebb, 1949) or the process in which "neurons that fire together, wire together". This is the neurological basis of memory and learning (Buonomano \& Merzenich, 1998).

\section{Developing A Change Mindset}

Many of us grow up learning that our various skills, whether "intellectual" or physical, are fixed biological traits. However, as school psychologists we must work with students to unravel this myth. Transforming a student's beliefs about the nature of intelligence, from a fixed entity to a set of modifiable characteristics, has a powerful effect on motivation and achievement. Carol 
Dweck, professor of psychology at Stanford University, and her colleagues have conducted fascinating studies illustrating the impact of a child's perceptions of intelligence on academic and cognitive performance.

Mueller and Dweck (1998) found that $5^{\text {th }}$ grade students who adopted an "entity theory" of intelligence, defining intelligence as stable trait, were more likely to endorse performance oriented goals, attributed low performance to low ability, were less likely to persist in the face of challenge, experienced less task enjoyment after setbacks, and their performance declined after experiencing failure. On the other hand, students who held an "incremental theory" of intelligence, perceiving ability as a quality that is malleable through hard work and learning, exhibited greater task persistence and task enjoyment even in the face of challenge. Furthermore, when confronted with a setback, these students were more likely to attribute poor performance to insufficient effort or strategy use rather than low ability.

Blackwell, Trzesniewski, and Dweck (2007) examined the educational impact of an 8 week intervention program teaching students the modifiable characteristics of the brain. The researchers taught junior high school students that intelligence was a dynamic and malleable characteristic that reflected one's effort and strategy use. The students were taught "that learning changes the brain by forming new connections and that students are in charge of this process" (p. 254). This was taught through readings, analogies, and examples, all of which were supported by activities and discussions.

Following the intervention, the students demonstrated knowledge of brain plasticity, were more likely to endorse an incremental theory of intelligence, and 3 times more students from the experimental group were reported by their teachers to demonstrate improvements in motivation and performance as compared to students in the control group. Furthermore, while math grades of students in the control group declined from pre to post intervention measurements, those in the experimental group were able to maintain and even slightly improve their math grades.

\section{Neuroplasticity And Academic Achievement.}

Adhering to the principles of neuroplasticity, Merzenich and his colleagues have developed interventions that capitalize on the brains ability to change in order to develop academic skills in children with learning disabilities. Tallal, Merzenich, Miller, and Jenkins (1998) found in two independent studies that children with language learning impairments showed marked improvements in language processing skills after 
four weeks of intensive computer based language listening exercises. These outcomes were attributed to the plasticity of the brain and that the language training exercises created changes in the structure and function of temporal processing areas.

The computer program employed by the researchers was designed to first establish a baseline of the child's temporal integration rates, in other words their ability to discriminate between subtle acoustic changes within syllables and words. The objective was to then close the gap between the child's current skills and more typical rates by gradually changing the auditory stimuli that the child is exposed to (e.g. from slower more deliberate speech segmentation to more typical speech rates). Tallal et. al. (1998) found that the program had the effect of "speeding up the temporal integration rates" of language learning impaired (LLI) children that participated in the studies.

The authors concluded from their data that "faster processing rates correlated significantly with improved ability to process individual speech sounds (phonemes) within words- a fundamental goal of both speech and language therapy for language impaired children, as well as phonological awareness training for reading impaired (dyslexic) children" (p. 198). Their initial program was then expanded to include 7 different computer based training exercises designed to improve auditory processing skills and marketed under the name Fast
ForWord (Tallal et. al. 1998). These researchers have since found the program to be effective in improving the language processing skills of children with language impairments as well as children with co-morbid central auditory processing disorder (CAPD), attention deficit/ hyperactivity disorders (AD/HD), reading disorders (dyslexia), and autism (Talla et. al., 1998).

\section{Conclusion}

Advances in neuroscience over the past 30 years teach us that the brain is not a fixed entity but rather a dynamic structure that is continuously altered by one's behavioral experiences. Active engagement in novel learning has been demonstrated to produce changes in the brain including new and larger neurons, greater numbers of dendrites, and increased branching of dendrites. Further, frequent activation of neural connections improve the strengths and efficiently of information processing.

As school psychologists, we must take active roles in promoting learning and behavioral changes in students experiencing educational difficulties. First, we can do this by promoting in students, as well as their parents and teachers, an "incremental theory" of intelligence in which "ability" is viewed as malleable quality that changes in response to active engagement in learning, hard work, and strategy use. Further, since we know that deficient 
cognitive processes change in response to targeted interventions, we actively advocate for the use of appropriate instructional strategies and provide students with ample opportunities to over learn skills needed to close the achievement gap between them and their typical learning peers.

\section{References}

BLACKWELL, L.S., Trzesniewski, K. H., \& Dweck, C.S. (2007). Implicit theories of intelligence predict achievement across an adolescent transition: A longitudinal study and an intervention. Child Development. 78 (1), 246-263.

BUONOMANO, D.V. \& Merzenich, M.M. (1998). Cortical plasticity: From synapses to maps. Annual Review of Neuroscience. 21, 149-86.

HEBB, D.O. (1949). The organization of behavior. Wiley, New York.

MUELLER, C. M. \& DWECK, C.S. (1998). Praise for intelligence can undermine children's motivation and performance. Journal of Personality and Social Psychology. 75 (1), 33-52.

ROSENZWEIG, M.R. (2003). Effects of differential experience on the brain and behavior. Developmental Neuropsychology. 24 (2\&3), 523-540.

TALLAL, P., Merzenich, M., Miller, S., \& Jenkins, W. (1998). Language learning impairment:
Integrating research and remediation. Scandinavian Journal of Psychology, 39. 1997-199. 